\title{
Systematising the Microstructure of a Modern Dictionary of the Arabic Language
}

Olzhas Mirzakhanovich Shayakhmetov, ${ }^{+*}$ Gulim Yesengaliyevna Imasheva, ${ }^{\dagger}$ Aliy Raufovich Almukhametov, ${ }^{\dagger}$ Rashid Srazhovich Mukhitdinov ${ }^{\complement}$ and Yktiyar Paltore ${ }^{\check{ }}$

\section{Abstract}

This article is concerned with studying the influence of conservatism on the modern Arabic lexicography, namely the structure of its dictionary entries and interpretation methods. "The Large Arabic Dictionary" of the Academy of the Arabic Language in Cairo has been chosen as the object of research since lexicographers regard it as the newest stage in the centuries-long evolution of the Arabic lexicography. Based on "The Large Arabic Dictionary", the comparative analysis touches upon the peculiarities of a modern general purpose dictionary of the Arabic language, definitions, methods of recording primary and derived verbs, and types of supporting data. The consistency between modern dictionaries of the Arabic language and their classical, medieval counterparts is analysed with regard to methods of organisation and interpretation. Omissions made by medieval lexicographers due to complex definitions and unsystematised dictionary entries are critically examined.

Keywords: Lexicography, General purpose Dictionary, Definition, Supporting data, Academy of the Arabic Language

\footnotetext{
${ }^{+}$University of Nur-Mubarak, Al-Farabi Ave, 73, Almaty, 050060, Kazakhstan

${ }^{*}$ Corresponding Author, Email: olzhasnm@mail.ru

İAl-Farabi Kazakh National University, Al-Farabi Ave, 73, Almaty, 050040, Kazakhstan

C2018 Shayakhmetov et al.. This is an Open Access article distributed under the terms of the Creative Commons Attribution License (http://creativecommons.org/licenses/by/2.0), which permits unrestricted use, distribution, and reproduction in any medium, provided the original work is properly cited.
} 


\section{Introduction}

Modern lexicographic handbooks of the Arabic language are based on reforms and centurieslong lexicographic traditions. Monolingual dictionaries compiled by the Academy of the Arabic Language in Cairo can be called the grand achievements of the modern Arabic lexicography, namely "al-Mu'jamal-uajīz" (the Abridged Arabic Dictionary), "al-Mu'jamaluasit" (the Middle Arabic Dictionary), and "alMu'jamal-kabī" (the Large Arabic Dictionary). The Abridged and Middle Arabic Dictionaries comprise vast lexical material aimed at a wide range of people from students to professional scientists. At the same time, "The Large Arabic Dictionary" compiled by the Academy of the Arabic Language in Cairo is relevant for the monolingual Arabic lexicography as it is based on the classical lexicographical principles and European traditions.

The reference point for monolingual linguistic dictionaries of the Arabic language is considered to be the explanatory dictionary "al'Ain" (8th century) by Halil ibn Ahmad (Nassar, 1988). The dictionary launched the beginning of the 14th-century practice of compiling monolingual dictionaries. However, despite such a long period of the Arabic lexicographic tradition formation, modern monolingual dictionaries of the Arabic language are still firmly committed to conservative methods of compiling dictionaries (Hablas, 2006). Therefore, the authors have attempted to analyse the degree of modernisation of modern dictionaries of the Arabic language. For this purpose, the "Big Dictionary" of the Cairo Academy of the Arabic Language was taken as the study subject, since it is the latest and largest project of the Academy (The Large Arabic Dictionary, 2006), and indeed represents the latest generation of monolingual dictionaries of the Arabic language. Speaking about the evolution of Arabic dictionaries, linguists mostly mean gradual changes in the arrangement of lexical units (the macrostructure of dictionaries), when groups of words with the same root are presented in a single dictionary entry in accordance with the root-vowel principle that was first introduced by Halil ibn Ahmad al-Farahidi (al-Hatib, 1987) in the 8th century. Thus, the Academy of the Arabic Language in Cairo has not drastically changed the macrostructure of traditional Arabic dictionaries. However, the systematisation of a dictionary entry is a result of all the reforms that took part in the practical Arabic lexicography.

The golden age of the Arabic linguistics in the 8th century marked the beginning of a centuries-long lexicographic tradition giving rise to a variety of dictionaries of different types, size and structure that are still widely used. The authors of the first dictionaries tried to preserve their literary language for interpreting religious texts (at-Tahanui, 1996). They paid much attention to gathering non-obscene words and arranging them in conformity with a method established by lexicographic schools while the systematisation of a dictionary entry was of no importance for them (al-Jilyali, 1999). Therefore, the users of early Arabic dictionaries had been facing severe problems till the end of the 19th century which arose from the following flaws in the macrostructure of dictionaries:

- No logical order of vocables within a group of words with the same root;

- Spontaneous definitions of field-related vocabulary;

- No definitions of archaisms;

- No unified method of forming verbs;

- Subjective choice of definitions and supporting data;

- Time-bound and locally constrained backing data;

- Lack of graphical supporting data;

- Lack of logic order in presenting supporting data;

- Complicated perception of definitions and supporting data.

Due to continuity, conservative principles and linguistic traditions not only influenced the classical Arabic lexicography but also caused certain drawbacks in modern dictionaries of the Arabic language. Therefore, when the Academy of the Arabic Language in Cairo was compiling 
the biggest dictionary in the history of the Arabic lexicography called "The Large Arabic Dictionary", it implemented several new ideas concerning the macrostructure of dictionaries.

This article explores the results of the analysis of the microstructure of the "Large Dictionary" of the Academy of Arabic Language in Cairo. The study pays attention to the explanatory and illustrative zones of a dictionary entry since the most of innovations introduced by the Academy were made precisely in these parts of the dictionary microstructure. To solve the task, a number of methods were applied, allowing a systematic (Apresyan, 1995, Danilenko, 2011) lexicographic analysis of the indicated zones of a dictionary entry.

\section{Methods}

The lexicographic method has been chosen as the primary research method since it makes it possible to systematically analyse the representation of linguistic units in dictionaries, ways of giving their definitions, procedures for compiling dictionaries, as well as to study in great detail the peculiarities and linguistic functions of the objects in such dictionaries (synonyms, antonyms, phraseological units, etc.) (Rybalkin, 1984). We also use other methods such as the contrastive-comparative method. This method is used to define the similar and distinguishing aspects in the concepts and structures adopted in "The Large Arabic Dictionary" and other thesauruses of the Arabic literary language. The statistic method deployed makes it possible to estimate and evaluate supporting data within an entry in "The Large Arabic Dictionary". Alongside, the modelling method used helps us to analyse word-building patterns, ways of adopting new words and defining them in a dictionary that is established by the Academy in Cairo. With the parametric method, the essential components of a dictionary entry are described. The component analysis contributes to the description of defining methods. Using the above techniques, the research resulted in revealing a number of innovations introduced by the Academy. This fact undoubtedly points to the transition of the Arabic monolingual lexicographic tradition to a new stage of development.

\section{Results}

The new microstructure of the modern Arabic dictionary is expressed using systematising introductory units within a group of same-root words, providing interpretation methods for native words and neologisms, giving etymological references as lexical equivalents from other Semitic and Oriental languages, offering supporting data (including graphics information) and presenting groups of same root words. Let us take a closer look at all these changes.

\section{Interpretation}

\section{The Arrangement of Introductory Units within a Group of Same-Root Words}

Classic Arabic dictionaries did not systematise lexical units within a group of same root words. Despite adopting various methods of arranging these groups (phonetical and permutative, alphabetical and circular, rhymed, alphabetical and root-related), the inner structure of the groups was left in complete chaos (Kushliy, 2002). For example, if one decides to find a derivative within a group of same-root words "da-ra-ba" in "Lisan al-'arab" Dictionary compiled by Ibn Manzur, a dictionary user would have to read all the entries within this group that make up even a bigger entry (longer than 15 pages).

The dictionaries compiled by the Academy in Cairo and "The Large Arabic Dictionary", in particular, provide a new microstructure where dictionary entries within a group of same-root words are divided into smaller entries for each introductory unit and are marked by the "*" symbol. The arrangement of these introductory units directly depends on the part of speech they belong to. It means that verbs precede nouns. Furthermore, priority is given to verbs with a single root-syllable in comparison with derived ones. Verbs with three letters in the root are regarded as nuclear forms compared to the ones with four or five letters. Then lexicographers also pay attention to the category of transitivity and intransitivity, 
phraseological features. They consider proper meaning to be the first one compared to metaphorical one; the same goes about abstract and material concepts. Unlike earlier dictionaries, the arrangement of quotations in "The Large Arabic Dictionary" follows the specific logic. Ancient lexicographers were mostly concerned with finding and documenting lexical units and ignored the problem of their arrangement within a dictionary. Thus, this problem had to be solved by the following generations of linguists.

Quotations in "The Large Arabic Dictionary" are arranged as follows:

- Context example;

- Quran quotations;

- Hadith ${ }^{1}$ quotations;

- Quotation from the Arabic prose;

- Abstract from some poems.

Quotations in the categories as mentioned earlier are also specifically arranged:

- Quran quotations are arranged following the arrangement of its Surahs, ${ }^{2}$ with common "al-mutauātir" recitals mentioned before "šauāz" ones.

- Their authenticity arranges hadith quotations, where "as-sahīh" (authentic) hadiths are mentioned first in comparison with "al-hasan" (good) ones, etc.

- Abstracts from the Arabic prose written by well-known authors are put earlier than quotations of some unknown authors; quotations within each group are arranged in chronological order.

- Quotations from the Arabic poetry are arranged in the same manner as quotations from the Arabic prose.

\section{Archaism Interpretation}

Lexical units documented in classical, medieval dictionaries served as a basis for most modern monolingual dictionaries of the Arabic language

\footnotetext{
1 The legend of the words and deeds of the Prophet Muhammad, telling about various religious and legal aspects of the life of the Muslim community (Boyko, 1991: 262-263)

${ }^{2}$ Each of the114 chapters of Quran is called «surah».
}

that adopted not only the units themselves but also the definitions provided. Due to this continuity, modern dictionaries mention a wide range of archaisms that are defined in an outof-date or complex manner (Hablas, 2006). In particular, field-related vocabulary documented on different stages of the development of the Arabic lexicography was defined about the development of the science of that time. The lexicographic works that survived to the day contain lexical units describing plants, animals, anatomy, and other branches, which need to be defined in the right way.

These problems were taken into consideration for compiling dictionaries of the Academy, including "The Large Arabic Dictionary", where field-related vocabulary and archaisms that came from earlier editions of dictionaries were given proper scientific descriptions revealing the nature of a lexical unit and their distinctive features. In order to evaluate the significance of these changes, let us analyse the definition of "al-babr" headword taken from "Lisan alarab" dictionary (the 13th century), which is the main source for "The Large Arabic Dictionary", and the definition of the same headword given by lexicographers behind "The Large Arabic Dictionary". Thus, in "Lisan alarab": "al-babr" (tiger) is an animal that looks like a lion but conflicts with it, a species of a carnivorous animal; a loan-word assimilated into the Arabic language" (Ibn Manzur, 1993, p. 306).

Even though the definition is primitive, it corresponds to the life period of the author. Though the presence of excessive banality in the interpretation of vocabulary in later dictionaries, up to the middle of the 20thcentury (Hablas, 2006), definitely indicates a stable continuity, inevitably generating a layer of archaisms in the explanatory zone of the dictionary entry. This also suggests a stagnation in the development of methods of interpretation. In the final part of the word definition "an Arabized word, of a foreign origin" one can trace the inherent desire of medieval lexicographers to separate the pure 
literary language of the era of the Islam birth, from any contamination with foreign vocabulary. This trend lasted until the appearance of the first monolingual dictionaries of the Cairo Academy in the middle of the 20th century (Nassar, 1988), when the academy announced new principles for the selection of lexical material, among which the concept of literary Arabic was considered without a time and local framework (The Large Arabic Dictionary, 2006, p. 7). Below we consider the definition of the same vocable, proposed by the "Large Dictionary".

"The Large Arabic Dictionary" offers a more detailed definition that is based on the Latin equivalent:

"al-babr" (Felistigris) is a large feline animal (Felidae), predator (Carnivora), mammal (Mammalia), with the body's length up to 3 meters, of a dark yellow color with thick black stripes, a white belly, stronger and more aggressive than a lion, can climb trees, swim, lives in Asian jungles" (The Large Arabic Dictionary, 2001, p. 32).

As we can see, the example contains an encyclopaedic reference adapted for a modern reader.

The definitions mentioned above manifest an important social function of dictionaries. Both lexicographic works recorded the sum of knowledge gathered in that period. The dictionary entry mentioned as the first example is based on the author's assumptions who seemed never to see a real tiger while the second example gives a more scientific and detailed definition.

\section{Neologism Interpretation}

The modern lexical system of the Arabic language, like any other well-developed national language, is being continuously enriched with new words through their adoption, polysemantic processes and semantic changes of existing widely used words. The Committee on the Control of Term Formation working under the Academy of the Arabic Language in Cairo has accomplished a great job unifying terms and sorting out new loan-words. As a rule, as an alternative to borrowed foreign vocabulary, the Cairo Academy uses the richest lexical potential of the Arabic language itself or adapts the borrowed vocabulary with the Arabic language system (al-Alami, 1990, p. 155). As the Arabic language has a lexical potential, terminologists managed to use the archaic words that had fallen from an active vocabulary in a new meaning instead of loanwords cluttering up the language. Thus, the "alqitār" word initially meant "a group of camels following one another", and now it denotes "a series of wagons that are attached to one another and dragged by a locomotive" (alqātira) (The Middle Arabic Dictionary, 2011, p. 716).

Examples of the vocabulary approved by the academy through this method are the equivalents presented in the following Table 1 , where the original Arabic vocabulary is proposed instead of direct borrowings.

The adaptation of the borrowed vocabulary in the Arabic language system is carried out under the morphological, grammatical and phonetic structure of the Arabic language. Newly-formed vocabulary is added to the glossary of the "Large Dictionary".

\section{General Meaning of Cognate Words within a Group of Same-Root Words}

Another change in modern dictionaries of the Academy of the Arabic Language, "The Large Arabic Dictionary" in particular, is a group of same-root words that mentions the meaning of a cognate word closely connected with derived lexical units within this group. The macrostructure of this dictionary is divided into several chapters, each of them marked by letters in alphabetical order, which form the nucleus of this group of same root words. All the derivatives within a group of same-root words are connected through a single word with a common semantic feature. 
Table 1: Translation Equivalent

\begin{tabular}{lll} 
The term in the language of borrowing & Equivalent A* & Equivalent B** \\
\hline Telephone & tilifūn & al-hātif \\
\hline Bonjour (French: Good morning) & būnjūr & sobāhan \\
\hline Bonsoir (French: Good evening) & būnsuār & masa-an \\
\hline Club & al-klūb & an-nādi \\
\hline Porte-manteau (French: hanger) & burt mantū & al-mašjab \\
\hline Carte (French: card) & kārt & bitaqa \\
\hline Police & būlīs & Šurti \\
\hline Salon & sālūn & bahu \\
$\begin{array}{l}\text { * Direct borrowing, which was in use before the Academy approved a new term. } \\
\text { ** Neologism, approved by the Cairo Academy to replace a direct borrowing and included in the } \\
\text { glossary of the "Large Dictionary". }\end{array}$
\end{tabular}

Therefore, each group of same-root words in

"The Large Arabic Dictionary" firstly mentions the common meaning of all the following words and only then present headwords. This method reveals the semantic similarity in a wordforming chain used for the search of a desired lexical unit that makes this dictionary easier to use. This structure of groups of same-root words was used in Ibn Faris' dictionary called "Makais al-luga" (Ibn Faris, 1979). The description of this semantic similarity in "The Large Arabic Dictionary" does not differ from the ideas expressed by Ibn Faris often quoted in the new dictionary. An innovation of "The Large Arabic Dictionary" is the systematic way of providing common meanings numbered and positioned from concrete to abstract meanings, and from proper to metaphorical ones. The group of same-root words "Hamza-ia-nun" in "The Large Arabic Dictionary" begins with the following meanings: 1. al-i'ya (exhaustion); 2 . qurbaš-šai (nearness). Then a quotation from Ibn Faris' "Makais al-luga" dictionary explains that "hamza-ia-nun" denotes both exhaustion and nearness. The first headword marked by the "*" symbol is given (The Large Arabic Dictionary, 2006, p. 660). It is a special feature of "The Large Arabic Dictionary" to mention the common cognate word, which makes this dictionary stand out from all the other modern monolingual dictionaries of the Arabic language. This method is important from a practical perspective as it is used for interpreting the lexical meaning of cognate words and mentions in the written form that related words have the same meaning typical of all the derivatives. At the same time, the common root meaning is primary, neutral in stylistic and is context-independent, unlike the secondary derivatives of lexical meanings generated as a result of historical evolution. In this connection, the common root meaning does not always have a direct reflection in the dictionary interpretations and can be implicitly contained in the etymological reference or as a result of the component analysis of the lexeme. Thus, the combination of the consonants " $j$ nun-nun" in the opinion of Ibn Faris forms the meaning "as-satr, at-tasattur" (covering, hiding), which is implicitly contained in the meanings of such derivatives as:

1. "al-janna" (garden): due to the density and cover effect created by tree branches;

2. "al-janīn" 1. (embryo): hidden in the womb of the mother;

3. "al-janīn" 2. (buried): hidden in the grave;

4. "al-janān" (heart): hidden in the chest;

5. "al-mijann" (shield): what is covering in the battle;

6. "al-jinna" (insanity): covering the mind;

7. "janan al-lail" (darkness of night): covering everything around;

8. "al-jinn" (jinn): they are called so because they are hidden from human eyes; 
9. "al-janājin" (breastbone): hidden in the chest (Ibn Faris, 1979, p. 421-422) ${ }^{3}$

The compilers of the "Large Dictionary" preferred to minimise the associativity of this combination of root consonants "j-nun-nun" by adding to Ibn Faris's meaning of "covering, hiding" the following variants of common root meanings, with a significant part of the lexical material of this word nest:

$$
\begin{aligned}
& \text { "as-satr, al-ihfā" (covering, hiding); } \\
& \text { "kasrat an-nabt" (abundance of plants); } \\
& \text { "al-halal az-zihni" (mental illness); }
\end{aligned}
$$

The relevance of these common root meanings with the lexical units of the word nest "j-nunnun" in the "Large Dictionary" is considered in the following Tables 2, 3 and 4.

The secondary nomination of objects of reality and the degree of their motivation are some of the most urgent issues of the Arab lexicography. One of the attempts to solve these problems is the "Large Dictionary" of the Academy of the Arabic Language in Cairo, where the common root has a systematic format.

\section{Giving Etymological References as Equivalents in Semitic Languages}

One more innovation of "The Large Arabic Dictionary" compared to previous and other modern dictionaries are the way it provides an etymological reference as equivalents in Semitic languages. Most equivalents mentioned in the dictionary belong to the Ethiopian, Aramaic, Syrian, and Hebrew languages, which are written in Latin letters and interpreted in one or another language. Some equivalents are given in the Persian language that does not fall into the Semitic group but since the 3rd century of the Hijrah ${ }^{4}$ it had adopted many Arabic words. The Arabic dictionary includes loanwords that have an etymological link and similar meanings in the Semitic languages

\footnotetext{
${ }^{3}$ Numbering and highlighting are made by the authors of the article.

4 The Muslim chronology, which is conducted from the date of resettlement of the prophet Muhammad and his followers from Mecca to Medina in the year 622 .
}

(languages with close cultural and historical connections), it helps to establish the mutual interference of these language groups and trace the development of these linguistic units in different time periods. Revealing lexical similarities and differences between related and unrelated languages, lexicographers also find incentives pushing the evolution of semantic meanings, which is useful for compiling the historical dictionary of the Arabic language - the next stage after "The Large Arabic Dictionary".

\section{Recording Verbs}

The next step in systematising a dictionary entry used by lexicographers is a new way of presenting verbs in the form of Past tense, Third person. Earlier Arabic dictionaries did not follow any precise idea of recording verbs and introduced them in past or present tenses, regardless of person, aspect and mood of particles (Mabruk, 2003). The lexicographers of "The Large Arabic Dictionary" also offered a new method of recording complex verbs with geminated letters inside a root like "radda", "šakka", "zalla", which change their forms while conjugating. Most early dictionaries give examples of verbs with geminated letters and their possible transformations, which form the vocalisation (harakat) of the middle letter inside a root in present tense like "radda" $\rightarrow$ "radadtu", "šakka" $\rightarrow$ "šakakna", "zalla" $\rightarrow$ "zalalna", etc. These examples use only attached object 1st and 2nd person pronouns, where geminated letters inside a root reveal themselves and are properly vocalised. There is no right descriptive sign to mark the middle letter inside a root in "The Large Arabic Dictionary" since the infinitive of verbs is represented by the form of past tense (third person).It gives an example of a regular verb that serves as a typical model for vocalisation patterns. For instance, "radda" is similar to "akala", that is, "radda" is conjugated in the same manner as "akala". However, this way of recording verbs is mostly used in the first part of "The Large Arabic Dictionary", in the second part dictionary users have to rely on their own language experience to define the middle 


\section{Table 2: The Common Root Meaning "as-satr, al-ihfä" (covering, hiding)}

\begin{tabular}{ll} 
Vocable & Interpretation \\
\hline Janna al-lail & Ištaddat zulmat al-lail (cover grew darker, the darkness of night) \\
\hline Janna fulān šai'a & Satarahu (hide smth) \\
\hline Janna al-maiit & Uārāhu (bury the dead) \\
\hline \hline 17 lexical items with the meaning
\end{tabular}

+17 lexical items with the meaning «hide, secrecy»

Table 3 - Common Root Meaning: "kasrat an-nabt" (abundance of plants, sprouting abundantly)

\begin{tabular}{ll} 
Vocable & Interpretation \\
\hline Junna an-nabat & Tala ua iltaffa, izdahara (sprouting abundantly) \\
\hline Junnat al-ard & Kasura nabatuha (the ground blossomed) \\
\hline Al-janna & $\begin{array}{l}\text { Al-hadīqa zāt an-nahl ua aš-šajar (a garden with trees and palm } \\
\text { trees) }\end{array}$
\end{tabular}

+ 6 lexical items with the meaning "abundance of plants, sprouting abundantly»

\section{Table 4 - Common Root Meaning: "al-halal az-zihni" (mental illness)}

\begin{tabular}{ll}
\hline Vocable & Interpretation \\
\hline Junna fulan & Zala 'aqluhu (go mad) \\
\hline Junna fulan bišai' ua minhu & u'jiba hatta iasir kal-majnun (become mad of admiration) \\
\hline Ajanna fulan & uaqa'a fi majanna (go mad, lose one's mind)
\end{tabular}

+5 lexical items with the meaning "mental illness"

geminated letter inside a root and its vocalisation methods. Thus, the doubled verb "baraa" in the second part of the dictionary does not have phonetic clues, and therefore, the definition of the middle root vowel of the verb is possible only with the user's own experience of conjugation of this verb.

Verbs in "The Large Arabic Dictionary" are distributed following the number of letters inside a root, with each form of a verb mentioned within a group of same root words. Forms of three-letter verbs ("za-Ila", "ja-Ila") and four-letter verbs ("za-I-za-la", "ja-l-ja-la") also fall into this category, which were mentioned within a single group of same-root words in early dictionaries (for example, "za-Iza-la" in the group of "za-lla", "ja-l-ja-la" in the group of "ja-lla", etc.) and made it hard to find necessary lexemes. A new way of recording verbs in "The Large Arabic Dictionary" corresponds to the initial concept of this dictionary and makes it fast and easy to find a desired lexical unit.

\section{Supporting Data Zone}

\section{Quotations from Literary Works}

Medieval authors behind early dictionaries of the Arabic language, like Al-Jawhari, Ibn Sid, AlAzhari, Ibn Faris, and others strived to achieve the integrity of the language and the right interpretation of religious sources, so they used texts dated back to the period no later than the 2nd century of the Hijrah (the 8th century) as supporting data. According to the compiler of the dictionary "as-sihah fi al-luga" (a correct one in the language) Al-Jawhari (940-1002): "The work contains only the correct vocabulary gathered from the lips of the true-bred Arabs" (Al-Jawhari, 1989: 15). Whereby, true-bred Arabs were supposed to live away from other nations (al-Farabi, 1986). Quotations written by later authors and authors getting in contact with foreigners were not included in the category of texts, which showed the right usage of lexical units and were used as examples of twisted literary meaning. Most medieval dictionaries with time-bound and locally constrained supporting data were characterised by a prescriptive nature and did not show the real discourse of that period. 
The analysis of supporting data in dictionaries compiled by the Academy of the Arabic Language in Cairo and in "The Large Arabic Dictionary" enables to divide the literary quotations used in the text into two major groups under periods of authors' lives:

Group I: excerpts were written by authors who lived in the period of fixing the Arabic vocabulary, whose works were used as a proof for some grammatical phenomenon, served as a lexical and semantic filter against nonArabic borrowings that could spoil the language and ruin the understanding of religious sources.

Group II: quotations written by authors who lived after the period of fixing the Arabic vocabulary (post-classical period and later), whose quotations did not serve as a linguistic argument, but were included into early dictionaries to demonstrate their wrong usage or acquisition of new semantic features by old lexemes. This category is headed by the Abbasid poet Bashār ibn Burd alUkaily (died in 167) because he started the epoch of the so-called "muhdasūn" authors who did not belong to the classical period of fixing the Arabic vocabulary, according to as-Suyuti (asSuyuti, 1988).

The analysis shows that "The Large Arabic Dictionary" uses many literary quotations taken from works written by authors from Group II. In the first part of "The Large Arabic Dictionary" there are 187 quotations written by 50 poets who lived after the period of fixing the Arabic vocabulary. They are Abu Tammam, alMutanabbi, al-Buhtari, Abu al-'ala al-Magri, Ibn ar-Rumi and Ibn Faris al-Hamadani. Figure 1 shows the frequency of quotations written by these authors and used in the first part of "The Large Arabic Dictionary":

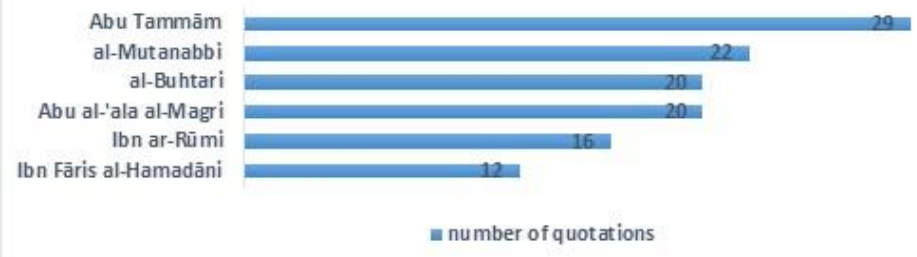

Figure 1: Frequency of Quotations Written by Authors from Group II in "The Large Arabic Dictionary."

The frequency of quotations written by other 44 authors ranges between 1 and 6 quotations. The rest of the authors from Group II is quoted once in the first part of the dictionary.

The fact that "The Large Arabic Dictionary" uses quotations written by authors from Group II proves that this lexicographic work is truly unique. However, the lack of modern quotations indicates that the concept of "The Large Arabic Dictionary" is heavily influenced by conservative tendencies.

\section{Graphic Supporting Data}

There are ideological reasons that ancient dictionaries of the Arabic language did not include any graphics supporting data to interpret lexical units. Drawings and maps were used for the first time in the "al-Wasiti" dictionary compiled by the Academy of the Arabic Language in Cairo for describing some animals, plants and geographical locations in an encyclopedia-like manner. "The Large Arabic Dictionary" also uses graphic illustrations in the form of historical portraits, geographical maps, and images depicting animals, plants and objects.

\section{Collective Work on "The Large Arabic Dictionary" Project}

The most important result of the reforms that took part in the Arabic lexicography under the influence of the Academy in Cairo is collective work on dictionaries. Modern academic 
dictionaries of the Arabic language were compiled; the credit for this goes to the research conducted by scholars and scientists working in different spheres. As lexicographers work in a team, it excludes a human factor. Individual efforts are insufficient, subjective, and unacceptable. The Academy of the Arabic Language in Cairo includes scholars from Iran, Syria, Tunisia, Lebanon, Morocco, Algeria, Libya, Palestine, Kingdom of Jordan, Saudi Arabia and Yemen. Literary critics made the working party of "The Large Arabic Dictionary", linguists, philosophers and other scholars who often ask assistance from their colleagues and academicians from other scientific spheres (The Large Arabic Dictionary, 2006, p. 6). Alongside the working party, there is also a committee on scientific, economic, architectural and artistic terms (Nassar, 1988, p. 590).

\section{Discussion}

Nowadays "The Large Arabic Dictionary" represents the biggest achievement of the centuries-long evolution of the Arabic lexicography. Its structural innovations comprise a systematised arrangement of introductory units within a group of same-root words, interpretation methods, interpretation of neologisms, etymological references as equivalents from other Semitic and Oriental languages, supporting data (including graphics information) and formation of groups of same root words. At the same time, the concept of "The Large Arabic Dictionary" is based on conservative methods of choosing a word-list, supporting data and metalanguage of interpretation.

\section{Level of Continuity}

The continuity of Arabic dictionaries becomes evident when one analyses the sources of quotations in the dictionary under study where religious texts and classical poetry written by authors for Group I are given a priority. Abstracts from the works written by authors from Group II are used less often, which proves a conservative approach was the main one for the compilation of "The Large Arabic Dictionary". During the history of the Arabic lexicography, dictionaries follow a specific tradition in choosing a word-list and supporting data, which aims to preserve the normative level of discourse, that is, the literary standard, in all the spheres of official communication. This tradition is still taken into consideration for compiling modern dictionaries and helps to highlight the unchangeable linguistic level common to all the social groups and life spheres. The same goes about supporting data, which includes Quran and hadith quotations, abstracts from ancient prose and poetry regardless of their interpretation of the chosen lexical unit and their semantic applicability.

\section{Neologism Interpretation}

The neologisms approved by the Academy of the Arabic Language in Cairo and later included into the word-list of "The Large Arabic Dictionary" are formed following classical methods developed by medieval linguists, namely:

- "at-ta'rībal-iqtibāsias-sauti" is a direct borrowing from a foreign language written employing the Arabic alphabet precisely or partially following the initial phonological structure, described by a Bașrī grammarian as-Sïbawayh (the 8th century);

- "at-ta'rībal-iqtibāsial-uad'l" is a complete transformation of a loan-word in accordance with morphology, grammar and phonetics of the Arabic language revealed by al-Jawhari (the 10th century) (al-Alami, 1990, p. 155). This type of a loan-word is also called "at-taulid" (Daif, 2004, p. 39).

The interpretation of neologisms completely depends on the two methods of adopting loanwords. When interpreting the term "pasteurisation" (from French Pasteurisation) authors of "The Large Arabic Dictionary" have two ways of building a dictionary entry and providing definitions. The first approach is to form the Arabic equivalent of this term through a direct borrowing described by as-Sībawayh (like "bāstūrīzāsiūn"). The second approach is to form an equivalent under al-Jawharī's method when a loan-word is fully adapted to the language system (like "al-bastara"). The 
first equivalent cannot give rise to any derivatives, so its contextual usage in various tense and mood forms like "pasteurised" (Past tense), "will pasteurise" (Present tense), "pasteurise" (Imperative mood) suggest auxiliary units and additional definitions. The second equivalent "al-bastara" is fully adapted to the morphological system of the Arabic language through many derivatives ("muštaqqāt"), which contains the interpretation of the given lexical unit within a single dictionary entry in accordance with a unified paradigm and mentions all the additional derivatives with their specific definitions. The interpretation model is as follows: "al-bastara" (Pasteurisation) $\Rightarrow$ definition $\Rightarrow$ "bas-ta-ra" (Past tense verb without definition) $\Rightarrow>$ "u-bas-ti-ru" (Present tense verb without definition) $=>$ "mubastir" (active participle: "pasteurising" without definition) $\Rightarrow>$ "mubastar" (passive particle: "pasteurised" without definition) => "bastari" (relative adjective: "pasteurising" without definition), etc.

\section{Denoting the Common Cognate Meaning of Derivatives}

Ancient linguists like Abu Ubaidah (728-839), alAsma'i (740-828), Shamir bin Hamdauiya (died in 869), al-Mubarrad (died in 899), Ibn Qutaybah (828-889), Qurra an-Naml (died in 922), az-Zudjadji (died in 951), Ibn Jinni (9411002), Ibn al-Anbari (884-940) and others took an interest in the ordinary cognate meaning of derivatives and covered both theoretical and practical aspects in their works. This practical aspect was revealed in the interpretation of lexical meanings of cognate words, with authors explicitly stating the ordinary meaning of these words. Ibn Faris (918-1002) used a well-systematised approach to study the analogous common sense in both theoretical and practical regard and recorded his ideas in the "Makais al-luga" dictionary, which served as a basis of the "Large Arabic Dictionary" and provided quotations for denoting the common cognate meaning. Lexicographers of "The Large Arabic Dictionary" mostly regard the common cognate meaning like Ibn Faris did, except for additional meanings used alongside the common one. As a result, the authors of "The Large Arabic Dictionary" not only adopted the explication of the common cognate meaning for lexical interpretation but also fully reproduced the model of presenting primary cognate meanings of lexical units in various semantic contexts andin accordance with ideas of medieval lexicographers.

The common cognate meaning is primary, stylistically neutral and does not depend on context, unlike secondary lexical meanings that were formed during the historical evolution of the Arabic language (Ibn Jinni, 1955). Therefore, the common cognate meaning is not always mentioned in dictionary interpretations and can be implicitly included into etymological references as a result of component analysis of lexemes.

\section{Collective Work on Dictionaries Compiled by the Academy of the Arabic Language in Cairo}

The idea to compile a dictionary by a group of authors was adopted from Western colleagues who represent scientific academies and work together on large lexicographic works of different types. However, it is still unclear whether "The Large Arabic Dictionary" should be regarded as a successful initiative if it has been in work for many years and has not been finished yet. The work on "The Large Arabic Dictionary" has been in progress for more than 70 years, and it is the oldest lexicographic project in history. A lack of funding could have explained this delay, but the Academy of the Arabic Language in Cairo submitted data on its annual budget, which is 7,000,000 EGP, or $272,200,000$ Kazakhstan tenge or 787,000 USD per year (Abd al-Mawla, 2007, p. 62). Therefore, critics explain the extended work on "The Large Arabic Dictionary" by the Eastern personality which strives to make oneself a name, create something unique and leave one's signature on the pages of history. When people work as a team, it changes the inner dynamics, and the one who works up a sweat is no different from all the others and gets the same reward in the end. This opinion can be supported by the fact that all the previous 
classical dictionaries are unique and compiled by individual authors.

\section{Conclusion}

"The Large Arabic Dictionary" is often seen as the latest contribution to the development of the modern Arabic lexicography. The peculiar microstructure of "The Large Arabic Dictionary" is expressed in systematised lexical units within a dictionary entry- new methods of fixing same-root words and their derivatives, mentioning common primary meanings of derivatives, unique ways of presenting definitions and supporting data.

Unlike in classical dictionaries, supporting data is not influenced by local or time constraints. The Academy of the Arabic Language in Cairo utilises traditional methods of adopting neologisms as equivalents to loan-words that are expressed in the definitions provided by "The Large Arabic Dictionary". However, the consistency of Arabic dictionaries becomes evident when one analyses quotations in the chosen dictionary and reveals that they are mostly taken from religious texts and classical poetry written by authors from Group I. The abstracts written by authors from Group II are used more rarely which proves that the compilation of "The Large Arabic Dictionary" has been made in accordance with the conservative approach.

\section{References}

Abd al-Mawla, M. (2007). Art of compiling dictionaries in the Academy of the Arabic Language in Cairo, Vol. 1, p. 144. Cairo: Academy of the Arabic Language in Cairo.

Apresyan, Yu. D. (1995). Selected works. Integral description of the language and systemic lexicography, Vol. 2. [in Russian]. Moscow.

al-Alami, I. H. (1990). Loan-words in the Arabic language, ISESCO, 34, 266-280.

al-Farabi, A. N. (1986). Kitab al-Huruf, p. 272. Beirut: Dar al-mashrik.

al-Hatib, A. S. (1987). Modern Arabic lexicography, p. 128. Beirut: Dar al-garb alislami.

al-Jilyali, H. (1999). Procedure of giving definitions in modern dictionaries of the
Arabic language, p. 384. Damascus: Union of Arabic Writers.

as-Suyuti, A. R. (1988). Al-Iktirah Fi ilm Usul AnNahv, Vol. 1, p. 112. Cairo: Academy of the Arabic Language in Cairo.

at-Tahanui, M. A. (1996). Encyclopedia of the art and science terms, p. 2185. Beirut: Maktaba Lubnannashirun.

Boyko, K. A. Prozorov, S. M. (Ed.). (1991). Islam: encyclopaedic dictionary, p. 315. [in Russian]. Moscow: Nauka, GRVL.

Daif, S. (2004). Scientific terminology. Collection of the Academy of the Arabic Language in Cairo, 102, 252-240.

Danilenko, V. P. (2011) Methods of linguistic analysis: a course of lectures [in Russian]. Moscow: Nauka.

Hablas, M. Y. (2006). Definition in the Arabic language. The Literary Journal of Ain Shams University, 34, 76-92.

Ibn Faris. (1979). Dictionary of Makais al-luga Vol. 2, p. 512. Amman.

Ibn Jinni. (1955). Al-Hasais, p. 585. Cairo: alHaya al-amma lil-kitab.

Ibn Manzur (1993). Lisan al-arab, Vol. 1, p. 566. Beirut: Dar al-Ihya al-Turas al-Arabi.

Kushliy, H. (2002). Evolution of the Arabic Dictionary from the 19th Century to 1950, (Research, analysis, criticism), (p. 456). Beirut: Dar al-minhal al-lubnani.

Mabruk, N. A. H. (2003). Studies of the Arabic lexicography, p. 320. Cairo: al-Amana.

Nassar, H. (1988). Lexicon Arab origins and evolution [in Arabic]. DarMisrliat-tiba'a.

Rybalkin, V. S. (1984). Principles of the construction of Arabic lexicographic works of the VIII-XVIII centuries: Candidate of Philology's dissertation thesis (p. 24) [in Russian]. Leningrad.

The Large Arabic Dictionary, Vol. 2. (2006). p. 700. Cairo: Academy of the Arabic Language in Cairo.

The Large Arabic Dictionary, Vol. 2, p. 768. (2006). Cairo: Academy of the Arabic Language in Cairo.

The Middle Arabic Dictionary, p. 1112. (2011). Cairo: Academy of the Arabic Language in Cairo. 